\title{
Preliminary evaluation of the role of activated carbon in soil/water remediation
}

\author{
VIKTOR MUKHIN ${ }^{1}$, NICOLAI KOROLEOV ${ }^{2}$, VALENTINA MEDNYAK ${ }^{2}$, TUDOR \\ LUPASCU $^{3}$, ELENA CULIGHIN ${ }^{3 *}$
}

${ }^{1}$ JSC ENPO “Neorganica”, 4 K. Marx str., Electrostal, Moscow region, 144001, VictorMukhin@yandex.ru, Russian Federation

${ }^{2}$ JSC “TopFarm”, 9A Ermakov blvd., Novokuznetsk, Kemerov region, 65007, Russian Federation

${ }^{3}$ Institute of Chemistry, 3 Academiei str., Chisinau, MD-2028, lupascut@ gmail.com, Republic of Moldova

*Corresponding author (e-mail): elena.culighin@ichem.md

$\begin{array}{lll}\text { Received: } & \text { Accepted: } & \text { Published: } \\ \text { 28.01.2021 } & 19.03 .2021 & 25.06 .2021\end{array}$

\begin{abstract}
This paper presents brief scientific information concerning the role of activated carbons $(A C)$ in solving economic and ecological problems in our society. Data concerning synthesis and adsorption of new activated carbons, used for soil remediation and wastewater treatment are depicted. The findings of investigations aimed to compare the structure parameters and adsorption capacities of the newly obtained native activated carbons in comparison with several activated carbon marks known in the world are explained. It has been shown that currently synthesized activated carbons are competitive with foreign marks.
\end{abstract}

Keywords: activated carbons, soil pollution, POPs

\section{INTRODUCTION}

Nowadays the environment encounters large, polluted areas, such as soils or sediments from landfills [1] and wastewater treatment. The reuse of these field soils is increasingly demanded due to urban expansion and their use in the agriculture. Similarly, polluted water poses risks to humans in urban (recreational) areas and to the environment in general. Progressive environmental pollution has made environmental safety an important component of national security in general. Remediation techniques are therefore urgently needed.

A wide range of environmental remediation approaches are discussed in the literature: ranging from soil washing [2], land farming [3], over phytoremediation [4], in situ chemical treatment [5-8], to dig-and-dump [9] and excavation. Among all these, activated carbon amendment has proven to be a promising option for the reclamation of such sites not only for organic but also for inorganic pollutants $[10,11]$.

Activated carbon is widely used in liquid phase applications that account for $35 \%$ to potable water, $25 \%$ to wastewater, $10 \%$ to groundwater, $10 \%$ to chemical processing and $20 \%$ to miscellaneous [12].

Carbon adsorbents are highly porous solids obtained based on carbon-containing raw materials (coal, wood, peat, etc.), that have a developed inner surface reaching $2500 \mathrm{~m}^{2} / \mathrm{g}$ and high absorption characteristics for impurities in the cleaned media (air, water, soil, etc.). Absorption of any types of organic micro impurities occurs in the porous structure of activated carbon (in the volume of micropores and mesopores) due to adsorption forces (surface interaction forces) [13]. There are globally significant environmental technologies for the use of activated carbons [14].

The purpose of this paper is to present the studies of some soil and water pollutants removal using activated carbons, which were obtained in Russia and Republic of Moldova. 


\section{EXPERIMENTAL PART}

\section{Soil remediation experiments}

Experiments on soil were carried out in an artificial climate laboratory (ACL) of the Russian Research Institute of Phytopathology RAS (Golitsyno, Moscow Region). To plant the test culture, pots with a capacity of $600 \mathrm{~g}$ of soil were used, which were spiked with the Treflan or 2,4dichlorophenoxyacetic acid (2,4-D) in the appropriate dose, and then a dose of AC was calculated at a rate of 100-200 kg per $1 \mathrm{ha}$, depending on the type and dose of the herbicide. After 30 days, the average weight of the test plant was evaluated by cutting off the vegetative mass of the plant at the level of the edge of the pot.

A mixture of sod-podzolic soil with sand and compost in a ratio of 1:1:1 was used as a soil substrate. Each soil sample of $3 \mathrm{~kg}$ was placed in plastic bags (according to the number of test options), moistened to a $60 \%$ moisture content, treated with an herbicide and thoroughly mixed.

One day after the soil was treated with herbicide, AC was introduced into it at doses of 100 and 200 $\mathrm{kg} / \mathrm{ha}$, then the soil mixture was thoroughly mixed and placed in disposable vegetation vessels with an amount of $600 \mathrm{~g}$ of soil (5 replicates for each option), after which the seeds were sown with test plants. As test plants tomato, carrots, and cereals were used. The control sample was of two types: soil samples not treated with herbicide and AC, as well as soil only with AC amendment.

Test plants ( 3 plants in each flowerpot) were placed in the chamber of an ACL and kept for 15 days at a temperature of $20^{\circ} \mathrm{C}$ during the day and $16^{\circ} \mathrm{C}$ at night with a longitude of 16 hours and night 8 hours; illumination of experimental plants in the daytime was 20 thousand lux. To maintain soil moisture at a level of 60-70\% of PV, water was piped daily.

After 15 days, the test plants were cut, weighed, and the presence of pesticides in the aerial mass of the experimental and control plants was compared.

\section{Water remediation experiments}

At the Research Institute of Municipal Water Supply and Water Treatment (RIMWSWT) (Moscow, Russia), the pilot batch of AC was investigated in the process of purifying drinking water from the most poorly adsorbed organic pollutants - formaldehyde and phenol under static conditions: $1 \mathrm{~g}$ of coal per 1 litre of water, contact time 0.5 hours.

Table 1 shows the technical characteristics of the DAS activated carbons and AG-3 industrial carbons (Russia, JSC Sorbent, based on SS brand coal) and GAC 830 (Netherlands, "Norit", based on coconut shell).

Table 1. Technical characteristics of the activated carbons used for water remediation

\begin{tabular}{l|ccc}
\hline \multicolumn{1}{c|}{ Indicators } & AG-3 & DAS & GAC 830 \\
\hline Bulk density, g/dm & $400-500$ & 780 & 550 \\
Abrasion resistance, \% & $70-75$ & 75.2 & 92.0 \\
Ash content, \% & $12-15$ & 2.2 & 2.4 \\
Micropore volume, $\mathrm{V}_{\Sigma}$ & & & \\
$-\quad \mathrm{cm}^{3} / \mathrm{g}$ & $0.2-0.22$ & 0.22 & 0.34 \\
$-\quad \mathrm{cm}^{3} / \mathrm{cm}^{3}$ & 0.09 & 0.17 & 0.19 \\
Adsorption activity by & & & \\
iodine, & & & 800 \\
$\quad \mathrm{mg} / \mathrm{g}$ & $650-670$ & 600 & 400 \\
\hline $\mathrm{mg} / \mathrm{cm}^{3}$ & 297 & 468 & \\
\hline
\end{tabular}

\section{Experiments in Republic of Moldova}

Three AC products were tested: one produced locally in Republic of Moldova (MD), and two produced by JSC ENPO "Neorganika” (Elektrostal, Moscow Region, Russia) (table 2).

Active carbons were tested in laboratory conditions in Republic of Moldova for elimination of $\alpha$ $\mathrm{HCH}, \beta$-HCH, $\gamma$-HCH,,$p^{\prime}$-DDT, $p, p^{\prime}$-DDT, $o, p^{\prime}$-DDE, $o, p^{\prime}$-DDD and $p, p^{\prime}$-DDD from water 
(initial concentrations ranging from 7 to $22 \mu \mathrm{g} / \mathrm{ml}$. The removal of the pollutants was calculated using the equation:

$$
\operatorname{Removal}(\%)=100 \times \frac{c_{t}}{c_{0}}
$$

where, $\mathrm{C}_{0}$ - initial concentration of the pollutant;

$\mathrm{C}_{\mathrm{t}}-$ concentration of the pollutant after AC amendment.

Table 2. Technical characteristics of the activated carbons

\begin{tabular}{l|ccc}
\hline \multicolumn{1}{c|}{ Characteristics } & MD & BAU-MF & AKU \\
\hline Sample description & $\begin{array}{c}\text { Apple wood AC, } \\
\text { (Ecosorbent SA) }\end{array}$ & $\begin{array}{c}\text { Charcoal AC, (NPO } \\
\text { "Neorganika") }\end{array}$ & $\begin{array}{c}\text { Apricot seeds AC, } \\
\text { (NPO "Neorganika") }\end{array}$ \\
Ash content, \% & 0.52 & 10 & 3.5 \\
Moisture content, \% & 15.4 & 6.3 & 3.8 \\
Methylene blue index, $\mathrm{mg} / \mathrm{g}$ & 120 & 210 & 290 \\
Iodine index, $\mathrm{mg} / \mathrm{g}$ & 842 & 700 & 1100 \\
Micropore volume, $\mathrm{cm}^{3} / \mathrm{g}$ & 0.264 & 0.32 & 0.61 \\
Total pore volume, $\mathrm{cm}^{3} / \mathrm{g}$ & 0.414 & 1.8 & 0.89 \\
\hline
\end{tabular}

Analytical determination was performed according to operational procedure based on ISO 10382:2002 (SM SR ISO 10382:2008) [15]. Instrumental determination was made on gas chromatograph 6890 systems of Agilent. System parameters were : injector type: split/splitless; temperature $-300^{\circ} \mathrm{C}$; injected volume- $2 \mu \mathrm{L}$; split $5: 1$; carrier gas: He $1.4 \mathrm{~mL} / \mathrm{min}$ or average velocity $30 \mathrm{~cm} / \mathrm{sec}$, constant flow; column type: HP-5MS length: $30 \mathrm{~m}$, internal diameter $320 \mu \mathrm{m}$, $0.25 \mu \mathrm{m}$ film thickness; detector: $\mu \mathrm{ECD}$, temperature $-3200^{\circ} \mathrm{C}$; oven program: initial: $100^{\circ} \mathrm{C}$ for 1 min, 1 st rate $20^{\circ} \mathrm{C} / \mathrm{min}$, isothermal: $200^{\circ} \mathrm{C}$ for $3 \mathrm{~min}, 2 \mathrm{nd}$ rate $10^{\circ} \mathrm{C} / \mathrm{min}$, isothermal: $280^{\circ} \mathrm{C}$ for 6 min; recorder/integrator: ChemStation, ChemStation Integrator [16].

Efficiency of activated carbon for removing organic pollutants from water was estimated by studying the kinetics of the process and the concentration of pollutants.

\section{RESULTS AND DISCUSSION}

\section{Soil remediation}

Herbicides widely used in crop production were used as soil contaminants. Products based on them retain phytotoxic activity in the soil for a long time, vegetable, oilseeds, and other broad-leaved crops are very sensitive to their residues $[17,18]$.

An important result of carbon-adsorption for soil remediation is to obtain environmentally friendly products of plant and vegetable production. Table 3 presents the results of comparative experimental studies on crops when they are cultivated according to conventional technology and using a carbon adsorbent.

Table 3. The accumulation of herbicides by crops

\begin{tabular}{c|cccc}
\hline Herbicide & $\begin{array}{c}\text { Herbicide } \\
\text { dose, } \mathrm{kg} / \mathrm{ha}\end{array}$ & AC dose, $\mathrm{kg} / \mathrm{ha}$ & Crop type & $\begin{array}{c}\text { Herbicide } \\
\text { concentration in } \\
\text { crop, } \mu \mathrm{g} / \mathrm{kg}\end{array}$ \\
\hline \multirow{3}{*}{ Treflan } & 1 & - & Tomatoes & 28 \\
& 1 & 100 & Carrot & 0.6 \\
& 1 & - & & 95 \\
& 1 & - & Not detected & 220 \\
$2,4-\mathrm{D}$ & 5 & 200 & Barley & Not detected \\
& 10 & - & & 670 \\
& 10 & 200 & Not detected \\
\hline
\end{tabular}


As it can be observed from Table 3, the application of activated carbons to contaminated sites in an amount of up to $100 \mathrm{~kg} / \mathrm{ha}$ (in the case of barley grain crops up to $200 \mathrm{~kg} / \mathrm{ha}$ ) can dramatically reduce, and in some cases eliminate the accumulation of herbicides in plant and vegetable products. Thus, the use of AC directly affects the nutrition and quality of life of a person.

\section{Water remediation}

To provide cities and large settlements with water of drinking quality, surface water from the water supply must be cleaned, and active carbons cannot be neglected [12].

The test results of anthracite-based activated carbon (DAS) and domestic AG-3 showed that DAS is not inferior to industrial carbons of domestic and foreign production.

Obviously, the micropore volume and consequently the adsorption properties per 1 volume unit of DAS activated carbon are on average 1.5 times higher than that of AG-3. At the same time, in terms of quality (except for hardness), DAS is even at the level of the some best world analogue [19].

The results of these tests are presented in table 4 .

Table 4. The effectiveness of drinking water purification from phenol by activated carbons (Test conditions: sorbate concentration of $50 \mathrm{mg} / \mathrm{dm}^{3}$, filtration rate of $4 \mathrm{~m} / \mathrm{h}$.).

\begin{tabular}{|c|c|c|c|}
\hline \multirow[t]{2}{*}{ Indicators } & \multicolumn{2}{|c|}{ Activated carbon type } & \multirow[t]{2}{*}{ Excess, times } \\
\hline & DAS & AG-3 & \\
\hline Sorption capacity before breakthrough $(\mathrm{mL} / \mathrm{g})$ & & & \\
\hline - bed height $120 \mathrm{~mm}$ & 9.4 & 2.15 & 3.8 \\
\hline - bed height $520 \mathrm{~mm}$ & 33.98 & 8.84 & \\
\hline Sorption capacity before saturation $(\mathrm{mL} / \mathrm{g})$ & & & \\
\hline - bed height $120 \mathrm{~mm}$ & 72.20 & 29.85 & 2.5 \\
\hline - bed height $520 \mathrm{~mm}$ & 94.00 & 38.16 & \\
\hline
\end{tabular}

In this case, as it could be observed, drinking water was filtered through active carbon columns and the advantage of DAS in the high volume of micropores per volume unit $\left(\mathrm{V}_{\mathrm{mi}}, \mathrm{cm}^{3} / \mathrm{cm}^{3}\right)$ was fully manifested. Thus, it can be stated that the sorption capacity for phenol on the DAS sorbent exceeds the sorption capacity of the industrially manufactured sorbent AG-3 (based on coal semi coke) approximately by 2.5-3.5 times. Sorbent DAS can be effectively used for purification of phenolcontaining wastewater as a load in sorption filters.

Based on the above study, it can be concluded that a simple replacement of sand or hydro anthracite loading in existing water supply systems with active anthracite (without building a separate block with activated carbon) on existing urban water supply systems will save a significant amount of budgetary funds, since the bulk density of active anthracite is comparable to the bulk density of quartz sand and it will not be washed out during backwashing of the filtration unit. In this case, both filtering of mechanical impurities and sorption of molecular toxicants will be carried out. This will provide high-quality clean and healthy water to the urban population without significant capital costs.

Persistent organic pollutants, as hexachlorocyclohexane $(\mathrm{HCH})$ and its isomers $(\alpha-\mathrm{HCH}, \beta$ - $\mathrm{HCH}, \gamma$ $\mathrm{HCH}$ ), as well as dichlorodiphenyltrichloroethane, its degradation products, and isomers (DDTs) negatively affect health by the occurrence of reproductive, developmental, behavioural, neurologic, endocrine, and immunologic adverse health effects [20-22].

It was shown that in the presence of activated carbon the entire amount of organic pollutants in water is retained. The results had shown that the efficiency of the AC decreases in the order: AKU $>\mathrm{BAU}-\mathrm{MF}>\mathrm{MD}$ for $\mathrm{HCHs}$ and $\mathrm{AKU} \approx \mathrm{BAU}-\mathrm{MF}>\mathrm{MD}$ (figure 1). It is important to underline that the pesticides removal exceeds $80 \%$ and the AC produced in Republic of Moldova is highly competitive to the commercial availably AC produced in Russia. 


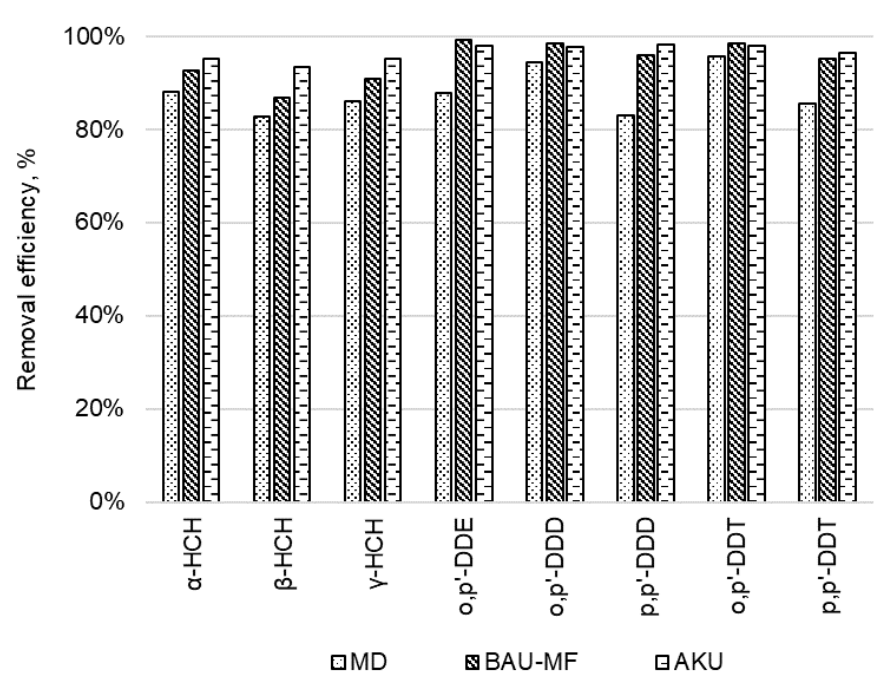

Fig 1. Removal efficiency of the $\mathrm{HCH}$ isomers $(\alpha-\mathrm{HCH}, \beta-\mathrm{HCH}, \gamma-\mathrm{HCH})$ and DDT, its degradation products and isomers ( $o, p^{\prime}$-DDT, $p, p^{\prime}$-DDT, $o, p^{\prime}$-DDE, $o, p^{\prime}$-DDD, $p, p^{\prime}$-DDD)

\section{CONCLUSIONS}

To implement the most important carbon-adsorption technologies described above that ensure the environmental safety of the countries, attention should be paid to the development of active carbon production.

Various aspects of human health at the present stage of development of society cannot be considered apart from the ecological state of the environment.

The results of experiments carried out in an artificial climate laboratory with different types and concentrations (corresponding to actual residual amounts) of herbicides in soils indicate that activated carbon is indeed a universal tool for restoring the fertility of contaminated soils regardless of the type and residual content of the herbicide, increasing productivity with $20 \%-100 \%$.

Environmental pollution, food and drinking water quality deterioration are certainly harmful to health; therefore, it is necessary to neutralize the negative effects of these factors on humans.

Thus, the high adsorption capacity of DAS activated carbon for phenol during industrial water treatment and treatment of industrial wastewater makes it possible to predict its high efficiency in water supply and sanitation systems.

The AC produced in Republic of Moldova is highly competitive in removal of organic pollutants from water along with other commercial marks of AC, removal efficiency exceeding $80 \%$

\section{REFERENCES}

[1] VITAli, M., CASTELlani, F., FRAGASSI, G., MASCITELli, A., MARTELlUCCI, C., DILETTI, G., SCAMOSCI, E., ASTOLFI, M. L., FABIANI, L., MASTRANTONIO, R., PROTANO, C., SPICA, V. R., MANZOLI, L., Sci. Total Environ., 762, 2021, p. 144100, https://doi.org/10.1016/j.scitotenv.2020.144100.

[2] RISER-ROBERTS, E., Remediation of petroleum contaminated soils - biological, physical, and chemical processes. Lewis Publishers, Boca Raton, 1998, 576 p.

[3] RHEZAJI, R. F., Oily sludge degradation study under arid conditions using a combination of landfarm and bioreactor technologies. Ph.D. Thesis, Memorial University of Newfoundland, Canada, 2002.

[4] PILON-SMITS, E., Annu. Rev. Plant Biol., 56, 2005, p. 15, https://doi.org/10.1146/annurev.arplant.56.032604.144214.

[5] SUTHERSAN, S., MCDONOUGH, J., SCHNOBRICH, M., DIVINE, C., Groundw. Monit. Remediat., 37, no. 1, 2017, p. 17.

[6] VITOlins, A. R., NELSON, B. R., UNDERHILl, S. A., THOMAS, L. A. M. H., Soil Sediment Contam., 12, no. 1, 2003, p. 139. 
[7] OLSON, M. R., BLOTEVOGEL, BORCH, J., T., PETERSEN, M. A., ROYER, R. A., SALE, T. C., Chemosphere, 114, 2014, p. 144, https://doi.org/10.1016/j.chemosphere.2014.03.109.

[8] DEVI, P., DAS, U., DALAI, A. K., Sci. Total Env., 571, 2016, p. 643, http://dx.doi.org/10.1016/j.scitotenv.2016.07.032.

[9] KUPPUSAMY, S., PALANISAMI, T., MEGHARAJ, M., VENKATESWARLU, K., NAIDU, R., Rev. Environ. Contam. Toxicol., Springer New York LLC, 2016, 236, pp. 1-115.

[10] HILBER, I., BUCHELI, T. D., Global Nest J., 12, no. 3, 2010, p. 305, https://doi.org/10.30955/gnj.000723.

[11] SOHI, S. P., Science, 338, no. 6110, 2012, p. 1034.

[12] BAKER, F. S., MILLER, C. E., REPIK, A. J., TOLLES, E. D., Kirk-Othmer Encyclopedia of Chemical Technology, John Wiley\&Sons, Inc., New Jersey, 2003, p. 741-761, http://doi.wiley.com/10.1002/0471238961.0103200902011105.a01.pub2.

[13] MENENDEZ-DIAZ, J. A., MARTIN-GULLON, I., Types of carbon adsorbents and their production. Activated carbon surfaces in environmental remediation (Interface Science and Technology Series, 7), Elsevier, 2006, p.1-47.

[14] AHMAD, M., RAJAPAKSHA, A. U., LIM, J. E., ZHANG, M., BOLAN, N., MOHAN, D., VITHANAGE, M., LEE, S.S., OK, Y.S., Chemosphere, 99, 2014, p. 19, https://doi.org/10.1016/j.chemosphere.2013.10.071.

[15] International Organization for Standardization, ISO 10382:2002 - Soil quality Determination of organochlorine pesticides and polychlorinated biphenyls - Gas-chromatographic method with electron capture detection, 2002. https://www.iso.org/obp/ui/\#iso:std:iso:10382:ed1:v1:en [25.11.2020]

[16] Agilent Technologies Understanding Your ChemStation. Available from: https://www.agilent.com/cs/library/usermanuals/Public/G2070-91126_Understanding.pdf

[10.03.2021]

[17] SAJID, M., BASHEER, C., NARASIMHAN, K., BUHMEIDA, A., AL QAHTANI, M., ALAHWAL, M. S., Nat. Environ. Pollut. Technol., 15, no. 2, 2016, p. 733.

[18] FRIMPONG, J. O., OFORI, E. S. K., YEBOAH, S., MARRI, D., OFFERI, B.K., APAATAH, F., SINTIM, J. O., OFORI-AYEH, E., OSAE, M., Ecotoxicol. Environ. Saf., 156, 2018, p. 205 https://doi.org/10.1016/j.ecoenv.2018.03.034.

[19] Cabot Corportion, "Norit® GAC 830 EN". Available from: www.cabotcorp.com.ar [10.03.2021]

[20] US EPA.: Persistent Organic Pollutants: A Global Issue, A Global Response https://www.epa.gov/international-cooperation/persistent-organic-pollutants-global-issue-globalresponse [25.11.2020]

[21] CHEN, M. W., SANTOS, H. M., QUE, D. E., GOU, Y. Y., TAYO, L. L., HSU, Y.-C., CHEN, Y.-B., CHEN, F.-A., CHAO, H.-R., HUANG, K.-L., Int. J. Environ. Res. Public Health, 15, no. 5, 2018, p. 931, https://doi.org/10.3390/ijerph15050931.

[22] The Concern About POPs - Persistent Organic Pollutants (POPs) Toolkit. Available from: http://www.popstoolkit.com/about/concern.aspx. [12.03.2021].

Citation: Mukhin, V., Koroleov, N., Mednyak, V., Lupascu, T., Culighin, E., Preliminary evaluation of the role of activated carbon in soil/water remediation, Rom. J. Ecol. Environ. Chem., 2021, 3, no.1, pp. 4-9.

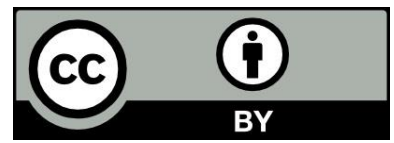

(C) 2021 by the authors. This article is an open access article distributed under the terms and conditions of the Creative Commons Attribution (CC BY) license (http://creativecommons.Org/licenses/by/4.0/). 